\title{
Genus är ingen självklarhet
}

\section{Av Solveig Fagerlund, doktorand i historia}

\author{
Länk till presentation av Solveig Fagerlund
}

Jonny Nilsson beskriver i detta nummer av HumaNetten genus som den nya tidens överideologi, som "medborgarna skall fostras i". Att anlägga ett genusperspektiv är enligt Jonny Nilsson - om jag förstår honom rätt - inte att vara kritisk mot dagens samhälle, bara att följa "det självklaras" tyranni. Men inget kan vara felaktigare än att betrakta genusperspektivet som självklart - inte i forskningen och framförallt inte ute i samhället.

Det finns emellertid risk för att det går inflation i begreppet och att det mister sitt analytiska värde när man betraktar genus som om det bar på en förklaring i sig själv. Det vill säga, om man förväntar sig att en genusanalys skall ge vissa svar, som att kvinnor är underordnade män, att kvinnor har blivit diskriminerade och så vidare, eller anser att alla frågor måste anlägga ett genusperspektiv. Men om man använder genus för att ställa nya frågor om hur relationer mellan män och kvinnor är konstruerade, hur maskulint, feminint, manligt och kvinnligt uppfattas och har uppfattats under historien, då är det ett fruktbart begrepp som förtjänar den uppmärksamhet det fått. Men att det, som Jonny Nilsson menar, har slagit igenom till den grad att andra forskningsinriktningar förlorar inflytande stämmer inte.

Även om det inrättats ett speciellt genussekretariat och en del forskningsmedel öronmärkts åt genusforskning innebär inte detta att genustänkandet genomsyrar vare sig universitet, riksdag, regering eller myndigheter. Det förs en kamp även inom dessa organ. Att man fattat beslut om att satsa på jämställdhets- och genusforskning beror inte på att jämställdhet mellan kvinnor och män är en självklarhet, för det självklara behöver man inte tala om. Snarare beror det på att trots att män och kvinnor i Sverige enligt lag är likställda är klyftorna dem emellan fortfarande stora både i lön för lika arbete, makt och inflytande i företag och offentlig sektor. Detsamma gäller hemmen, där kvinnan fortfarande utför merparten av hushållsarbetet även om bägge makar förvärvsarbetar i lika stor utsträckning (se bl.a. SOU 1997:83, Kvinnovetenskaplig tidskrift 1999:1). Att ifrågasätta det rättmätiga i dessa skillnader i dagens samhälle är, enligt min mening, just en sådan kritisk reflektion av rådande värderingar som Jonny Nilsson efterlyser. Jonny Nilsson menar att studenter mer eller mindre pressas till att anlägga ett genusperspektiv. Detta betvivlar jag starkt.

Växjö universitets nye rektor Magnus Söderström säger följande om internationalisering: "Det finns en snacknivå både när det gäller genusperspektiv och internationella perspektiv. Poängen är att göra något konkret" (Universitetsläraren 1999:17). Och hur mycket konkret görs egentligen av genusperspektivet inom forskningen? Här följer några exempel ur den svenska verkligheten. Av 492 svenskspråkiga avhandlingar publicerade 1999 fanns 11 med ett klart uttalat genusperspektiv och ytterligare 11 med sökorden män/kvinnor (Libris). Vid psykologiska institutionen i Uppsala vägrade en professor i psykologi i år, 1999(!) att examinera en uppsats om den byggde på feministisk orientering (Genus 1999:3).

Ute i samhället har inte heller genus eller jämställdhetstankar fått det genomslag Jonny Nilsson menar. Även om ett fåtal välutbildade feministiska skribenter tagit plats på DN:s kultursida och lyckats reta upp en stor del av den manliga kultureliten innebär det inte att kvinnorna är på väg att ta över makten i samhället. Med utgångspunkt i min egen erfarenhet törs jag påstå att för en stor del av Sveriges befolkning är genus bara en grammatisk term, om ens det, och jämställdhet mellan män och kvinnor fortfarande en chimär. 
